\title{
Women and the Transmission of Religious Knowledge in Islam
}

Asma Sayeed

New York: Cambridge University Press, 2013, 220 sayfa.

Kitap, 2005’te Amerika Birleşik Devletleri’nin Princeton Üniversitesi’nde tamamlanan "Shifting Fortunes: Women and Hadith Transmission in Islamic History" başlıklı doktora tezinin geliştirilmiş şeklidir. Kadınların İslâm’ın ilk on asrı boyunca hadis rivayetine katılımlarını konu alan çalışma, müslüman hanımların ilim hayatındaki rollerini dönemlere göre değișen yoğunlukları ve sebep-sonuç ilişkileri çerçevesinde tahlil etmektedir.

Sayeed'e göre, sahâbe döneminde Peygamber efendimizin hanımları başta olmak üzere kadınların hadis rivayetine ciddi bir iştiraki söz konusudur. Resûlullah’ın diğer akrabalarıyla (meselâ kızı Fâtıma) ilk müslüman olanların ve cephe gerisinde savaşlara katılan hanımların da hadis râvileri olarak öne çıktıkları bu dönemin en mühim şahsiyetleri Hz. Âişe ve Ümmü Seleme'dir. $\mathrm{Bu}$ iki isim, çok sayıda hadis rivayet etmek gibi bilinen özelliklerinin yanı sıra ilk İslâm toplumunun muhtelif kesimleri tarafından daha sık ve rahat ulaşılabilir olma (meselâ soru sormak üzere gelen elçileri kabul etme) gibi yönleriyle öne çıkmışlardır. Sahâbe devrinde, sonraki nesillerin râvilerinde aranacak şartlar henüz vazedilmediğinden, kadınların hadis rivayetine daha serbest ve hayatın tabii akışı içinde gelişen bir tarzda katıldıkları görülür.

Sayeed, II. (VIII.) yüzyılın başından IV. (X.) yüzyılın ortalarına kadar kadınların ilim hayatına katılımlarının belirgin biçimde azaldığını kaydeder. Ona göre, büyük tâbiîn tabakasında Ümmü'd-Derdâ el-Vassâbiyye es-Suğrâ (ö. 81/701) ve Amre bint Abdurrahman (ö. 106/724) gibi fikıh bilgisi veya dindarlığ nemlerde kadınların ilmî rolleri asgari düzeye inmiştir. Genellikle bir veya iki hocadan hadis nakleden hanımlar yaygın bir tedvin faaliyetine girişmemişlerdir. Yazar bunun başlica sebepleri olarak hadis rivayetinin II. (VIII.) yüzyılda uzmanlık ve yüksek nitelikler gerektiren müstakil bir disiplin haline gelmesini, ehl-i re’y ile ehl-i hadis arasındaki tartışmaların fıkıh ve kelâm bilgisine vurguyu arttırmasını ve mahremsiz seyahat edemeyen kadınların ilim rıhleleri yapmakta erkekler kadar özgür olamamasını göstermektedir.

Mezkûr gerekçelerin ve bunlarla bağlantılı kitapta geçen tespitlerin çoğu isabetli olsa da, râvilerde fıkhî kavrayış şartının kadınların aleyhine işleyen 
bir sebep olduğunu söylemek pek mümkün değildir. Zira fikhî yahut kelâmî yeterlilik erkek râvilerde de aranmamaktadır. Dolayısıyla hususan bu gerekçede fazlaca idealize edilmiş bir râvi tanımından bahsedildiği söylenebilir. Ayrıca kadınların ilmî çevrelerden uzak kaldığı dönemin sonu olarak kitapta bazan IV. (X.) yüzyıl (s. 187), bazan da IV. (X.) yüzyılın ortaları (s. 108) işaretlenmiş, ancak biyografi kaynaklarından hareketle bu devrin V. (XI.) asrın başına kadar uzatılabileceği vurgulanmıştır (s. 91).

Yazara göre, müslüman hanımlar IV-V. (X-XI.) yüzyıldan X. (XVI.) yüzyıla kadar ilimle tekrar yoğun biçimde meşgul olmuşlardır. Ders aldıkları hocaların sayısı artmış, az hadis nakleden "râviye"lerin yanında çok miktarda hadis nakleden "muhaddise"ler ortaya çımış, meşhur hadis eserlerinin rivayet isnatlarında yer alanlar ise İslâmî kitap kültürünün oluşumuna katkı yapmışlardır. Güvenilir hadis kitapları üzerinde yaygın bir kabulün oluşmasıyla beraber hadis faaliyetinin uzman olmayanların katılımına müsaade edecek şekilde esneklik kazanması, kadınların ilim tahsilini kısıtlayan rıhle ve semâ metodu üzerindeki vurgunun azalması ve ulemâ ailelerinin kız çocuklarına sundukları imkânlar, bu dönemki canlanışın başlıca sebepleri arasındadır. Yazara göre, ailevî irtibatların sunduğu tahsil fırsatları kadınların nâmahrem sorununu kısmen aşmalarını sağlamıştır. Öte yandan "icâzet"in yaygınlaşması, akrabaları sayesinde küçük yaşta icâzet alan hanımları, erkeklerden ortalama olarak daha uzun yaşamaları sebebiyle âlî isnatlar için aranır hale getirmiştir.

Kitapta bu dönemden ilim hayatları örnek olarak incelenen hanımlar yaklaşık 100 yaşına kadar yaşadığı belirtilen Sahîhu'l-Buhârî râvilerinden Kerîme el-Merveziyye (ö. 463/1070), mutasavvıf Abdülkerîm el-Kuşeyrînin hanımı Fâtıma bint Hasan b. Ali ed-Dekkāk (ö. 480/1088), Şühde el-Kâtibe (ö. 574/1178), çok sayıda icâzetin sahibi Zeyneb bint Kemâl (ö. 740/1339) ve Âişe bint Muhammed b. Abdülhâdîdir (ö. 816/1413). Bu isimlerin ortak noktaları kadınların yanı sıra pek çok erkek talebeye hocalık yapmaları, medrese sistemi dışındaki eğitimde yer almaları (informel eğitimin İslâm tarihi boyunca kadınlar için büyük bir fırsat olduğu vurgulanmıştır) ve küçük yaşlarda eğitime başlamış olmalarıdır.

İslâm tarihinin Selçuklu, Eyyûbî ve Memlük idarelerini kapsayan bu uzun dönemine dair yazarın üç tespitinin daha altını çizmek gerekir. İlk olarak, dinî yönden ciddi sınırlamalara konu olmuş kadın-erkek ilişkilerinde ilim tahsili söz konusu olduğunda uygulamada belli bir esneklik gösterildiği anlaşılmaktadır. İkinci olarak yazar, kadınların ilme iştirakinin, bir sosyal sınıf olarak ulemânın kendini tahkim etme çabalarına da katkı yaptığını 
vurgulamıştır. Dikkat çekilen bir diğer nokta ise, kadınların ilimle meşguliyetinin fikıh ve kelâm gibi alanlardan ziyade hadis üzerinden gerçekleşmesidir.

Kadınlar nakletmek üzere genellikle hadis eserlerini tercih ederken, onların katılımı konusunda çekinceli davranması beklenebilecek Sünnî gruplar, hatta en koyu Hanbelîler dahi bu katılımı içselleştirmiş bir görüntü çizmişlerdir. Bu bağlamda yazar, Sünnîlik’teki “traditionalism” diye adlandırdığı gelenek vurgusunun oluşumunda kadınların oynadığı role dikkat çekmekte (s. 146-148), onları ilme teşvik etme bakımından Sünnîliğin Mûtezile’den çok ileride olduğunu öne sürmektedir. Ayrıca kitaba göre, kadınların ilimle iştigal yoğunlukları açısından hadisle mukayese edilebilecek alan tasavvuftur ki incelenen dönemde bir kısmı hadisle de meşgul olmuş sûfî hanımların varllğ 1 belirgindir.

Sayeed, Osmanlı̉nın Suriye ve Mısır'da hâkimiyet alanlarını genişlettiği X. (XVI.) yüzyıldan itibaren kadınların ilim sahnesinden tekrar çekildiğini kaydeder (s. 180-185). Bunun, hadiste rivayetin yerine artık dirayetin öne çıkmasından ve Osmanlı ile birlikte kurumsal eğitimin ve onun merkezindeki fıkhın ağırlık kazanmasından kaynaklandığını savunur. Kadınların bu dönemdeki başlıca ilgi alanı tasavvuftur. Ne var ki kitapta yalnızca beş sayfalık yer tutan bu son dönem hakkında henüz yeterince çalışma yapılmadığını yazar da kabul etmiş ve tespitlerinde ihtiyat payı bırakmıştır. Esasen Osmanlı’nın bu yönden müstakil olarak çalışılması daha isabetli olacaktır.

Kitap, müslüman kadınların ilmî hayattaki rollerini inişlerine ve çıkş̧larına göre dönemlere ayırarak başarılı bir tarihsel tablo ortaya koymakta, sebep-sonuç ilişkilerini vurgulamaya özen göstermektedir. Yazar, kadınların bütün İslâm tarihi boyunca eğitim sahasında yoğun olarak rol aldıkları şeklindeki naif görüşün yanlışlığını ispat ettiği gibi, kadınların sahâbe döneminden sonraki azalan katılımını Yahudilik, Hıristiyanlık, Bizans veya Sâsânî kültürlerinin tesirine bağlayan araştırmacıları da eleştirmektedir (s. 76, 105107). Gerekçeleri İslâm dünyasının içinde aramak gerektiğini düşünen Sayeed, cinsiyet çalışmalarında yaygın olan tepkisellik, ön yargı ve aşırı genelleme gibi kusurlardan uzak durarak soğuk kanlı bir analiz sunmaktadır.

Eserde kadınların hadis faaliyetine katılımı, onların hadis isnatlarının hangi tabakalarında bulunduklarının belirlenmesiyle ortaya çıkarılmış, ayrıca ulaşılan kanaatler tarih ve biyografi literatüründen delillerle desteklenmiştir. İsnat verilerini rical kayıtlarıyla desteklemesi, kitabın kaynak kullanımı açısından altı çizilmesi gereken hususiyetlerindendir. Bu bağlamda kütüb-i tiśa ve başka birtakım temel hadis eserlerinin yanında İbn Sa'd’ın 
(ö. 230/845) Kitâbü't-Tabakātil'-kebîr'i, İbn Hibbân'nn (ö. 354/965) es-Sikāt'1, İbn Asâkir'in (ö. 571/1176) Târîhu Dımaşk'ı, İbn Hacer el-Askalânînin (ö. 853/1449) ed-Dürerül-kâmine'si, Sehâvînin (ö. 902/1497) ed-Dav'ül-lâmii i gibi rical ve tabakat eserlerine sıkça başvurulmuştur. Kadınların Sünnî ulemâ kesimine katkılarından bahsedilirken Batı'da ulemâ üzerine çalışmış Richard W. Bulliet ve Michael Chamberlain'in çalışmalarına, "ortodoksi” hakkındaki tahlilleri vesilesiyle de antropolog Talal Asad'in fikirlerine atıf yapılmıştır.

Konusu gereği hadis tarihiyle beraber eğitim ve bilgi sosyolojisi sahalarını da ilgilendiren kitapta, sosyal bilimlere ait kavram ve yaklaşımlara yer verilmiştir. Özellikle kadınların ilmî kazanımları vurgulanırken kullanılan "social capital" (sosyal sermaye) terimi başta olmak üzere Fransız sosyolog Pierre Bourdieu’nün etkisi belirgindir. Yazar sosyolojik tahlilleriyle eserini zenginleştirip genel okuyucuya da hitap ederken, hadis araştırmalarında incelenen konunun toplumun en geniş kültür dairesi içinde nereye tekabül ettiğini göstermenin ne kadar önemli olduğunu zımnen hatırlatmaktadır.

Batı akademisinin hadise karşı geleneksel şüpheciliği, yazarı kitabın başında bir açıllama yapmaya zorlamıştır. Kendisinin kadınların naklettiği hadislerin sıhhatiyle değil, sonraki nesillerin onları nasıl aldığıyla ilgilendiğini söyleyen Sayeed, çalışmasını İslâm tarihi alanında konumlandırarak şüpheci oryantalistlerden gelmesi muhtemel itirazları cevaplamıştır (s. 11-12). Onun böyle bir savunma ihtiyacı hissetmesi, hadislerin shhatiyle ilgili kaba oryantalist yargıların İngilizce yazan dünyada hâlâ etkili olduğunun işaretidir.

Sade bir anlatıma sahip olan eser, bir taraftan kadınların ilimle meşguliyetlerini incelerken diğer taraftan hadis tarihinin bilhassa müteahhirîn devrinin anlaşılmasına önemli bir katkı yapmıştır. Yukarıda sayılan özellikleriyle kitabın, kadın muhaddislere dair ülkemizde yapılmış olan biyografi ağırlıklı çalışmalara taze bir soluk getirme potansiyeli mevcuttur, bu sebeple Türkçe’ye tercüme edilmesinin isabetli olacağ 1 söylenebilir.

\section{Macit Karagözoğlu}

Yrd. Doç. Dr., Marmara Üniversitesi İlâhiyat Fakültesi 